\title{
AN ANALYSIS OF ENGLISH ABSTRACT WRITTEN BY THE PARTICIPANTS ON NATIONAL SEMINAR PROCEEDING
}

\author{
Siti Nuraminah"), Pipit Rahayu ${ }^{2)}$ \\ Sitinuraminah127@gmail.com,darariau2010@gmail.com \\ English Department, University of Pasir Pengaraian
}

\begin{abstract}
This research investigated about the English Abstract Written By The Participants on national proceeding conducted by University of Pasir Pengaraian. The purpose of this research was to analyzed English Abstract Written By The Participants. This research was descriptive qualitative design. The population of this research was 45 abstract. The sample of this research was 45 abstract. The data was to analyzed by three raters. Based on the two indicator that have given by the researcher. The result of this research that showed based on the first indicator was categorized in good level, mean while The result of this research based on the second indicator was categorized in fair level. The weaknesses of the participants in writing abstract, most of them did not write the conclusion in their abstract. The weaknesses of the participants in writing abstract, most of them did not written the conclusion, suggestion, and not using ARIAL 11 in their abstract.
\end{abstract}

Key Words: abstract, National Seminar Proceeding, writing

\section{INTRODUCTION}

Writing is one of the important skills in English. Writing is a literary work that appears through the creative ideas the someone in a her/his written to read by the reader. According to Nunan (2003:88), writing is the mental work of inventing ideas, thinking about how to express them, and organizing them into statements and paragraphs that will be clear to leader. Writing is a complex cognitive activity that is done by the students and many people. It might be began from sentence, text, essay as the people think, because they should use correct dictions, chronologies, and spelling of word.

The activities that usually in writing is writing text. In writing text, we should express our ideas to make some paragraphs and can to arrange 
each paragraph be cohesively and coherently. Therefore, writing is not easy. Not only for students, but also to lecturers. The lectures should master in writing skill, especially in writing abstract, because in a thesis or a journal must be there English abstract in it.

An abstract is a summarize of the research form that has made by a researcher, that can be read by the readers as a source of new knowledge and can be a source of reference for the research in accordance with the study of the reader. According to Silyn and Roberts (2013:54), an abstract presents the overview to an expert audience. Required in specialized documents such as journal papers, conference papers and posters. With the purpose" to give the reader an overview of all of the key information in the thesis: objective, methods, results, conclusions, contribution to originality (Silyn and Roberts, 2013:148). So, writing abstract should made accordance procedure or the steps well. Because an abstract must be there in a thesis or journal to make the readers are easy to be know the content of the thesis or journal.

In 2018, University of Pasir Pengaraian conducted National Seminar that attended by many participants. The participants were the lecturers University of Pasir Pengaraian and the lecturers outside University of Pasir Pengaraian. There are 111 articles that written by the lecturers on National Seminar Proceeding. On National Seminar Proceeding there are many researches made by the lecturers. In research journal, there was abstract that used English language. To make the abstract in English language is not easy. Because must be mastered in procedure of writing English abstract.

On the National Seminar Proceeding conducted by University of Pasir Pengaraian, not only the all participants who came from The English Department. There were came from engineering, agriculture, mathematic, biology, and others. Especially the participants who came outside English Department, they were not learn about English writing abstract. There were some of the lecturers who ask for the lecturers' English department for help them to translate their abstract in English language. Not only participants from not The English Department that feel difficult in writing English abstract, but the participants from English Department too. Many 
articles that have been read by the researcher about writing abstract, that writing abstract is not easy, because it requires not only a good level of proficiency of a foreign language but also to think in a foreign language and structure the main ideas clearly and logically. An abstract must be cohesively and coherently, so that the reader can be gets the point from a research. Based on researcher observation, the researcher found the reasons about it; firstly, writing an abstract must be there on a research, likes a thesis, an article or journal, secondly, writing English abstract is not easy to all people especially to the lecturers because must be mastered in procedure of writing abstract, thirdly the all lecturers or participants need the writing an abstract in their research, and the last, not all the lecturers who came from the English Department.

Based on the reasons above, the researcher interested to conducted a research about writing English abstract with the title "An Analysis of English Abstract Written By The Participants On The National Seminar Proceeding Conducted By University of Pasir Pengaraian".

\section{REVIEW OF THE RELATED THEORIES}

Writing is the work of someone through ideas and aspirations in written form. According to Soles, Perez, and Fuentes (2007:279) states writing is necessary to transmit the merits of your work, your ideas and aspirations. That is the way of writer to communicate with the readers. The writer follows the rules of grammar, spelling, punctuations, and sentences structure in writing.

In writing, a writer needs a good strategy to get the best result writing. $\mathrm{He} / \mathrm{She}$ needs the process in writing. According to Soles, Perez, and Fuentes (2007: 32), writing process composed of three main stages. Firstly, Prewriting. Before beginning to write you should invest some time planning what to write and how to transmit the information. In order to do this you should consider (a) audience and purpose (who you are writing to and why), (b) tone and style (how you transmit the information), (c) gathering of information (brainstorming analyzing sources of information, etc.) and (d) outlining (organization of information). Secondly, Writing. Once you have 
gathered and organized the information, you can begin writing a first draft. At this stage, it is important to consider the main parts of the text, paragraph development and coherence as well as genre conventions. As you revise and consider all these aspects, it may be helpful to use representative models as a reference. And the thirdly, Postwriting. The final stage of the writing process involves (a) revising content and organizing, (b) checking for grammatical accuracy (c) editing for style and (d) proofreading and peer produce a flawless final version.

An abstract is a part that should be stand alone, which the reader does not have to look the other parts. An abstract is a succinct summary of a longer piece of work, which is published in isolation from the main text and should therefore stand on its own and be understandable without reference to the longer piece, (Simkhada, Teijlingen, 2013). An abstract must be there clear of the points. Therefore, writing abstract is very important in article or thesis. The abstract is a factual summary of a much longer report. According to Pierson (2004:1207) an abstract is a condensed version of a full scientific paper, it describes a study and its results. It is mean, an abstract explain about what is the background of the research, how to solve the problems of the research and what is aim of the research. So, the reader will be know the contents of the research, after the readers read the abstract of that research.

Writing an abstract is one of difficult parts, because it is a most important part in a research and an abstract is a part that always read by the reader. According to Jalalian (2012:520) writing an abstract properly is one of the most highly-specialized forms a academic writing. The abstract, which is a very vital part of a journal article, comes first in the article, but it is the last part to be written. To write the abstract, the writer must be carefully. Because an abstract must be neatly arranged and the content must be clear to the readers, so that it is easy to understand. According to Jalalian (2012:522) there are writing parts of the abstract, likes introduction, methods, results, and conclusion that it all must be neatly arranged.

The aim of an abstract is to report the result of a research to the readers. The abstract talks about the 
summary of a research. The structure of abstract must be neatly and clearly. So that, the readers can know about what was problem of research and how to solve that problem of the research. In this research, the researcher used 2 indicators. There are the on proposed by Pierson and the template on National Seminar Proceeding conducted by University of Pasir Pengaraian. According to Pierson (2004:1207) the structured of an abstract must be arranged by: a) Title; it should be an accurate promise of the abstract's contents. b) Authors; author lists are rough rank orders of the relative contributions of the persons named, with the exception that the senior author (the mentor) is often listed last. c) Introduction or Background; there are the general descriptions about the reason and purpose of the research. d) Methods; explain about method and procedure that used in the research. e) Results; to tell the reader what the findings of the data study were. f) Conclusion; there is last statement from the researcher or author in a research.

From the statement above, it is clear that a good abstract have all the components. From the abstract, the researcher will give the result of the research or study. Beginning from title, the authors, background, method, result, and conclusion, the researcher must be conclude in make an abstract. The abstract made by researcher to give information about the content of their research.

Indicators of abstract based on Template of National Seminar Proceeding conducted by University of Pasir Pengaraian, there are: a) Introduction, this is first part of abstract and should be brief and attractive to the readers at the same time. b) Objective, your goal; what the study examined and why. c) Method, brief description of the study. d) Result, findings and observations. e) Conclusion, this is usually answers the question: what do your findings mean? f) Suggestion, an idea or plan put forward for consideration. g) No more 200 words, using the words in abstract no more 200 words. h) Using ARIAL 11 and single space.

\section{RESEARCH METHODOLOGY}

In this study, the researcher used the descriptive qualitative. According Sugiyono (2005) states that the descriptive method is a method used to describe or analyze a research result but 
not used to make broader conclusions.

Qualitative research is the collection, analysis, and interpretation of comprehensive narrative and visual (non numerical) data to gain insights into a particular phenomenon of interest (Gay, 2012:7). The researcher took the data from on National Seminar Proceeding conducted by University of Pasir Pengaraian. the totally of population in this research were 45 English abstract written by The Participants on that journal. In this research, the sample were 45 English abstract written by The Participants on that journal. There were 2 indicators of abstract that used as instrument in this research, they were based on Pierson Theory and based on Template of National Seminar Proceeding conducted by University of Pasir Pengaraian. The steps were the researcher choose the English abstract by the participants as sample of the research. Then, researcher choose three raters in analyzed the English abstract by the participants based on the indicator of writing abstract. And then, the researcher gave rate of English Abstract Written by The Participants with used scoring rubric writing.

\section{FINDINGS AND DISCUSSION}

The researcher used two references in analyzed, there were based on Pierson Theory and Based on Template of National Seminar Proceeding conducted by University of Pasir Pengaraian. Indicator based on the Pierson such as title, author, background, method, result, and conclusion. Mean while, indicator based on Template of National Seminar proceeding conducted by University of Pasir Pengaraian such as introduction, objective, method, result, conclusion, suggestion, no more than 200 words, and using ARIAL 11 and single space.

Based on the data from rater 1 to 3 who were analyzed the English abstract written by the participants and the data could be categorized in the following table below:

Table 1.

The summary of English abstract written by the participants from the all raters

\begin{tabular}{|c|c|c|c|c|}
\hline No. & Score Range & Frequency & Percentage & Quality \\
\hline 1. & $85-100$ & 7 & $15,56 \%$ & Excellent \\
\hline
\end{tabular}




\begin{tabular}{|c|c|c|c|c|}
\hline 2. & $70-84$ & 23 & $51,11 \%$ & Good \\
\hline 3. & $55-69$ & 12 & $26,67 \%$ & Fair \\
\hline 4. & $50-54$ & 3 & $6,67 \%$ & Poor \\
\hline 5. & $0-49$ & - & 0 & Very Poor \\
\hline & Total & 45 & \multicolumn{2}{|c|}{$100 \%$} \\
\hline
\end{tabular}

The data above showed that the frequency of total summary of English abstract written by the participants could be divided in some categories. They were 7 participants who got the excellent level, 23 participants who got the good level, and 3 participants who got the poor level. So, the researcher could concluded that the summary of English abstract written by the participants were categorized in good abstract. Because, the researcher found most of the participants score in the good level with percentage $51,11 \%$.

Based on the data from rater 1 to 3 who were analyzed the English abstract written by the participants in English writing abstract and the data could be categorized the lecturers' skill in English writing abstract in the following table below:

Table 23.

The summary of English abstract written by the participants from the all raters based on Template of UPP

\begin{tabular}{|c|c|c|c|c|}
\hline No. & Score Range & Frequency & Percentage & Quality \\
\hline 1. & $85-100$ & - & - & Excellent \\
\hline 2. & $70-84$ & 12 & $26,67 \%$ & Good \\
\hline 3. & $55-69$ & 22 & $48,89 \%$ & Fair \\
\hline 4. & $50-54$ & 5 & $11,11 \%$ & Poor \\
\hline 5. & $0-49$ & 6 & 13,33 & Very Poor \\
\hline
\end{tabular}


The data above showed that the frequency of total summary of English abstract written by the participants could be divided in some categories. They were 12 participants who got the good level, 22 participants who got the fair level, 5 participants who got the poor level, and 6 participants who got the very poor level. So, the researcher could concluded that the summary of English abstract written by the participants were categorized in fair abstract. Because, the researcher found most of the participants score in the fair level with percentage $48,89 \%$.

The result of the research based on Pierson Theory showed the participants were categorized fair level in writing title of abstract, excellent level in writing author, excellent level in writing introduction, excellent level in writing method, excellent level in writing result, and very poor level in writing conclusion. The result also showed that the frequency of total summary of English abstract written by the participants could be divided in some categories. They were the participants got the excellent level were 7 participants , 23 participants who got the good level, and 12 participants who got the fair level, 3 participants who got poor level.

So, the researcher concluded that the summary of English abstract written by the participants were categorized in good level. Because, the researcher found most of the participants' score in good level or $51,11 \%$. From the totally summary of English abstract written by the participants got the good level.

The result of the research based on template of National Seminar Proceeding conducted by University of Pasir Pengaraian showed the participants were categorized excellent level in writing introduction in an abstract, excellent level in writing objective, excellent level in writing method, excellent level in writing result, very poor level in writing conclusion, very poor level in writing suggestion, excellent level in using word, and very poor level in using ARIAL 11 and single space. The result also showed that the frequency of total summary of English abstract written by the participants could be divided in some categories. They were the participants got the good level were 12participants , 22 participants who got the fair level, 5 participants who got the poor level, and 
6 participants who got the very poor level.

So, the researcher concluded that summary of English abstract written by the participants were categorized in fair level or $48,89 \%$. The totally of summary English abstract written by the participants got the fair level.

\section{CONCLUSION AND SUGGESTION}

The result of the research based on Pierson Theory showed that the participants were categorized excellent level in writing title, excellent level in writing author, excellent level in writing introduction, excellent level in writing method, excellent level in writing result, and very poor level in writing conclusion. From the result above, the researcher concluded that the weaknesses of the participants in writing abstract were they did not write the conclusion in their abstract, most of them only enough in the result.

The second result of the research based on Template of National Seminar Proceeding conducted by University of Pasir Pengaraian, the participants were categorized excellent level in writing introduction, excellent level in objective, excellent level in writing method, excellent level in writing result, very poor level in writing conclusion, very poor level in writing suggestion, excellent level in using 200 words, and very poor level in using ARIAL 11 and single space. From the result above, the researcher concluded that the weaknesses of the participants in writing abstract were they did not written the conclusion, suggestion, and not using ARIAL 11 in their abstract. They always made an abstract only till in result part.

Further, by the finding of this research the researcher offers some suggestions as the following: 1) For the students, to add knowledge in parts of abstract, especially in how to write an abstract. 2) For the next researcher, the researcher suggest to the next researcher to find out the other relevant in writing abstract likes how to make an abstract well. 3) For the lecturers, to gives some evaluation in make an English abstract. There were some suggestion that will be given for the next graduation, especially writing abstract: they have to consult with the advisor or English lecturers to translate their abstract, they have to consider use of English and grammar if they want to write an English abstract, and they have to consider and put the systematic of abstract based on the 
expert suggestion in writing English abstract.

\section{REFERENCES}

Gay, L.R., Mills, Geoffrey F., Airisian, Peter w.2012.Educational Research (Tenth Edition).New York:Pearson.

Jalalian, Mehrdad.2012.Writing An eye Catching and Evocative Abstract for a Research Article: A Comprehensive and Practical Approach.In http://www.ephysician.ir.

Retrieved on January 12019.

Nunan, David.2003.Practical Engllish Language Teaching.McGrawHillELT:Australia

Pierson, David J.2004.How to Write That Will Be Accepted for Presentation at A National Meeting.Retrieved on October 2004.Vol. 49 No. 10.

Silyn, Heater \& Roberts.2013.Writing for Science and Engineering(Second

Edition).New Zealand:lsivier.

Simkhada, Padam.,Simkhada, Bibha., Van Teijlingen, Edwin Roland
\& Hundley V.2015.Writing An Abstract for A scientific Conference.In

https://www.researchgate.net/p ublication/259808073.Retrieve d on January 82019.

Soles, Carmen Bombardo., Perez, Marta Aguilar \& Fuentes, Claudia Barahona.2007.Technical Writing.Spanish:Politext.

Sugiyono.2013.Metode Penelitian Kuantitatif Kualitatif Dan R\&D.Jakarta:Alfabeta. 